\title{
ANALISIS PENGARUH PELATIHAN DAN LINGKUNGAN KERJA TERHADAP KINERJA KARYAWAN PT. COCA-COLA BOTTLING INDONESIA
}

\begin{abstract}
Eddy Sanusi. S *
Abstract: This research was titled "Influence Analysis of Training and Work Environment To Employees Performance at PT Coca-Cola Bottling Indonesia" The purpose of this research was to obtain the information about ralationship between independent variable which is training (X1) and work environment (X2) with variable dependent which is employees performance $(\mathrm{Y})$, either through partial and also by simultan. Research method that was used is with approach of Explanatory Analysis that was explained relationship of causality between variable

Sampling techniques can be done randomly (simple random sampling) of the 1400 respondents, by using the formula Slovin, samples can be used only 93 employees.

Results of this research are: 1). Simultaneously training and work environment have a positive impact, relatively strong and significant to work employees performance at PT Coca-Cola Bottling Indonesia. This is indicated by acquisition of R-Square amount of $78 \%$ and the remaining $22 \%$ is influenced by other factors which not examined, those are leadership and motivation. 2). Partially training has a positive effect, relatively strong and significant to work employees performance at PT Coca-Cola Bottling Indonesia. This is indicated by acquisition of R-Square amount of $66 \%$. 3). Partially work environment have a positive impact, relatively strong and significant to work employees performance at PT Coca-Cola Bottling Indonesia. This is indicated by the acquisition of R-square amount of $47 \%$.
\end{abstract}

Kata kunci : Pelatihan, lingkungan kerja dan kinerja karyawan

\section{PENDAHULUAN}

Organisasi yang baik, tumbuh dan berkembang akan menitikberatkan pada sumber daya manusia (human resources) guna menjalankan fungsinya dengan optimal, khususnya menghadapi dinamika perubahan lingkungan yang terjadi. Dengan demikian kemampuan teknis, teoritis, konseptual, moral dari para pelaku organisasi / perusahaan di semua tingkat (level) pekerjaan amat dibutuhkan. Selain itu pula kedudukan sumber daya manusia pada posisi yang paling tinggi berguna untuk mendorong perusahaan menampilkan norma perilaku, nilai dan keyakinan sebagai sarana penting dalam peningkatan kinerjanya.

Seiring dengan perkembangannya perusahaan sering kali mengabaikan tentang pengelolaan sumber daya manusia yang dimilikinya. Kendatipun sering terdengar isu tentang pentingnya pengelolaan sumber daya manusia di lingkungan perusahaan, tetapi penanganannya secara terencana dan terfokus, baik oleh perusahaan maupun individu sebagai karyawan itu sendiri jarang dilakukan.

Untuk menghadapi persaingan maka perusahaan perlu untuk menuntut kinerja karyawan yang tinggi dari karyawannya, dimana kinerja karyawan yang diharapkan tersebut salah satunya dipengaruhi oleh pelatihan dan lingkungan kerja. Menurut Payaman J. Simanjuntak (2005), kinerja adalah tingkat pencapaian hasil atas pelaksaan tugas

\footnotetext{
* Eddy Sanusi. S adalah dosen tetap Fakultas Ekonomi Universitas Krisnadwipayana, Jakarta
} 
tertentu. Kinerja perusahaan adalah tingkat pencapaian hasil dalam rangka mewujudkan tujuan perusahaan. Lebih lanjut Payaman J. Simanjuntak, menyatakan bahwa konsep kinerja sama halnya dengan konsep produktivitas, konsep produktivitas nilai hasil yang dicapai dibandingkan dengan masukan yang digunakan. Sementara dalam konsep kinerja, hasil yang dicapai dibandingkan terhadap sasaran atau rencana yang telah ditetapkan lebih dahulu. Konsep produktivitas harus memperhitungkan nilai masukan, sementara konsep kinerja lebih menekankan kesesuaian pencapaian hasil dengan rencana.

Adapun faktor-faktor yang dapat mempengaruhi kinerja salah satunya dengan memperhatikan masalah pelatihan. Pentingnya pelatihan bukanlah semata-mata bagi karyawan yang bersangkutan, tetapi juga keuntungan organisasi. Karena dengan meningkatnya kemampuan atau keterampilan para karyawan, dapat meningkatkan produktivitas kerja para karyawan. Produktivitas kerja meningkat berarti organisasi yang bersangkutan akan memperoleh keuntungan (Soekidjo, 2003).

Freeman (1999), menyatakan bahwa, kegiatan pelatihan pada dasarnya dilaksanakan untuk menghasilkan perubahan tingkah laku dari karyawan yang mengikuti pelatihan. Perubahan tingkah laku yang dimaksud disini adalah dapat berupa bertambahnya pengetahuan, keahlian, keterampilan, serta perubahan sikap dan prilaku

Selain pelatihan, lingkungan kerja memegang peranan yang juga amat penting dalam pelaksanaan kerja karyawan. Sebagaimana yang diungkapkan oleh Stoner dan Freeman (2002), Lingkungan kerja merupakan lingkungan dimana tempat orang bekerja. Lingkungan kerja maksudnya adalah keseluruhan alat perkakas dan bahan yang dihadapi, lingkungan kerja sekitarnya dimana seseorang bekerja, metode kerjanya, serta pengaturan kerjanya baik bagi sebagai perorangan maupun sebagai kelompok. Lingkungan kerja sangat perlu diperhatikan untuk menjamin agar karyawan dapat melaksanakan tugas tanpa mengalami gangguan. Memperhatikan kondisi lingkungan kerja karyawan dalam hal ini berarti berusaha menciptakan kondisi lingkungan kerja yang baik dan nyaman, sehingga efisiensi kerja suatu organisasi dapat tercapai dengan baik. Dengan demikian sangat penting bagi pimpinan prusahaan untuk memperhatikan hal ini, sebagai salah satu cara untuk meningkatkan semangat kerja karyawannya dan juga kinerja karyawan.

Adapun faktor yang dapat mempengaruhi kedua faktor diatas untuk meningkatkan kinerja di dalam perusahaan yaitu kepemimpinan dan motivasi. Dalam hal ini pengaruh seorang pimpinan sangat menentukan, karena untuk merealisasikan tujuan, perusahaan perlu menerapkan gaya kepemimpinan atau pola kerja yang konsisten terhadap situasi kerja yang dihadapi. Selain itu seorang pimpinan memelihara hubungan yang baik dengan bawahannya agar mereka dapat bekerja secara produktif. Dengan demikian, secara tidak langsung pun kinerja perusahaan dapat ditingkatkan. Begitu juga motivasi, Adanya rangsangan merupakan bentuk motivasi yang dapat diberikan kepada setiap karyawan agar mereka bekerja lebih baik dan bertanggungjawab. Karena itulah, manajemen perlu memahami faktor-faktor apa yang dapat digunakan untuk merangsang para karyawan agar bekerja lebih baik.

Berbagai referensi sebagaimana dikemukakan diatas, peneliti akan mengkaitkannya pada fenomena yang terjadi di PT. Coca-Cola Bottling Indonesia yang bergerak dalam bidang pembuatan minuman. Berdasarkan hasil pengamatan yang dilakukan PT. CocaCola Bottling Indonesia ternyata masih terdapat beberapa permasalahan yaitu lingkungan kerja yang kurang kondusif seperti fasilitas kerja yang kurang kompetitif seperti mesin-mesin yang sering merusak teliga dengan suara atau kebisingan yang mengganggu konsentrasi dalam bekerja.

Berdasarkan pernyataan diatas diketahui bahwa perlu adanya peningkatan 
kinerja karyawan PT. Coca-Cola Bottling Indonesia yang berkaitan dengan pelatihan dan lingkungan kerja. Hal ini berarti karyawan memerlukan motivasi kerja yang kuat agar bersedia melaksanakan pekerjaan secara bersemangat dan produktif.

Tujuan penulisan ini adalah ingin mengetahui berapa besar pengaruh pelatihan dan lingkungan kerja terhadap kinerja karyawan PT. Coca-Cola Bottling Indonesia.

\section{KERANGKA TEORI}

\section{Pengertian Pelatihan}

Salah satu upaya organisasi dalam meningkatkan daya saing untuk menghadapi persaingan dimasa mendatang adalah dengan memanfaatkan kemajuan ilmu pengetahuan dan teknologi. Penggunaan dan penguasaan teknologi dapat meningkatkan efektifitas, effisiensi serta mampu menghasilkan barang dan jasa yang berkualitas bila didukung oleh tenaga kerja yang berkualitas tinggi. Tenaga kerja yang berkualitas diharapkan mampu menjalankan peralatan yang berteknologi tinggi dan secara berkesinambungan melalui latihan. Pelatihan adalah proses belajar dengan menggunakan teknik dan metode tertentu untuk meningkatkan keterampilan kerja seseorang atau sekelompok orang (Jeffey Mello: 1999).

Pelatihan kerja sebagai bagian dari investasi sumber daya manusia bertujuan membentuk dan menambah pengetahuan seorang mengenai pekerjaan dan lingkungan kerja, serta cara mengerjakan sesuatu pekerjaan dengan cepat dan tepat. Pelatihan kerja diperlukan untuk mengembangkan sumber daya manusia mengingat bahwa dalam kenyataan terdapat pengetahuan dan keterampilan yang secara khusus tidak diberikan dalam pendidikan formal. Pengetahuan dan keterampilan yang demikian pada umumnya diperoleh melalui pengalaman kerja maupun pelatihan yang diperoleh dari kursus atau pendidikan non formal lainnya (Djaslim Saladin : 1995).

\section{Sistem Pelatihan}

Secara umum pelatihan sumber daya manusia dimaksudkan menanggalkan segala persoalan kinerja yang mengalami defisiensi, penyakit ini menyebabkan karyawan tidak dapat menunjukkan performa kerja pada tingkatan yang telah distandarisasikan organisasi mengalami stagnasi dan bahkan penurunan rates of productivity, dalam konteks yang demikian itulah pelatihan memiliki posisi strategis guna meningkatkan kinerja dan kapabilitas karyawan. Training Need Analysis (TNA) berfungsi sebagai fundamen informasi bagi manajer dalam menetapkan program pelatihan dalam segala formatnya, oleh karena itu pada bagian diulas satu tahapan pokok dalam pelatihan yang berkaitan dengan analisis kebutuhan pelatihan. Menurut Schuler (1992), merumuskan "Pelatihan menjadi 3 (tiga) tahapan integrative yaitu sebagai berikut : a). Assesment phase, sebagai tahap yang sangat penting untuk menentukan kebutuhan apa saja yang harus diakomodasikan dalam pelatihan termasuk juga bagaimana format dan rancangan pelatihan yang akan diimplementasikan. b). Implementation phase, adalah mengimplementasikan seluruh keputusan tentang pelatihan yang dihasilkan dari tahap assesmen phase, selain menterjemahkan setiap informasi, dalam hal ini manajer juga membuat strategi tentang bagaimana pelatihan secara teknis akan dilaksanakan, strategi ini juga mencakup tentang alokasi, waktu, pelatihan, dan seterusnya. c). Evaluation phase, dimaksudkan untuk memastikan bahwa pelatihan yang dilaksanakan telah mencapai target yang ditentukan, 
oleh karena itu kegiatan utama manajer adalah mengadakan pengukuran sampai sejauh mana efektifitas pelatihan dapat dicapai.

\section{Metode Pelatihan}

Metode pelatihan ada banyak dan berbeda-beda, beberapa metode adalah berguna untuk kelompok-kelompok manajemen dan karyawan-karyawan tertentu, metode yang lain adalah berguna untuk masalah pokok khusus tetapi metode yang lain lagi mempunyai bermacam-macam kegunaan. Salah satu fungsi latihan profesional adalah untuk memilih metode atau metode yang paling cocok untuk suatu program latihan tertentu. Pengelompokkan metode pelatihan untuk karyawan dapat dikelompokkan menjadi 4 (empat), yaitu : a). On the job training; Merupakan metode latihan yang paling banyak dipergunakan, yang dilakukan di tempat kerja atau dalam ruang kelas, sistem ini terutama memberikan tugas kepada atasan langsung dan karyawan yang baru dilatih untuk melatih mereka. b). Vestibule schools; Pelatihannya adalah pelatih-pelatih khusus atau staff biasanya menitik pada metode melaksanakan pekerjaan dari pada mendapatkan hasilnya. c). Magang; Dipakai untuk pekerjaan yang memerlukan keterampilan yang relatif lebih tinggi, dan merupakan gabungan dari on the job training dan pengalaman dengan menggunakan petunjuk-petunjuk dalam pengetahuan-pengetahuan tertentu. d). Konferensi; Meliput kelompok yang terdiri dari 30 - 60 orang peserta dimana semua peserta didorong untuk mengambil bagian dalam pembicaraan tentang masalah-masalah pokok pembicaraan.

\section{Implementasi Pelatihan}

Metode Schuller, Dowling, (1992), "Pertimbangan utama yang harus diperhatikan mencakup 6 (enam) perkara, yaitu : a). Siapa yang harus ikut sebagai partisipan dalam pelatihan; b). Siapa yang memberi pengajaran; c). Media apakah yang digunakan dalam proses pembelajaran; d). Pada tingkat (level) pembelajaran apakah pelatihan diadakan; e). Prinsip-prinsip rancangan pelatihan apakah yang dibutuhkan. f). Dimana program akan dilakukan"

\section{Evaluasi Pelatihan}

Bahwa evaluasi secara sistematis berkaitan dengan persoalan sampai sejauh mana pelatihan dapat memberikan nilai bagi instansi sehingga mampu mengikuti perubahan perkembangan teknologi.

Evaluasi pelatihan berdasarkan model sistem mengacu pada 5 (lima) sistem, yaitu: a). Masukan (input); b). Sistem pemrosesan (the processing system) atau proses transformasi; c). Keluaran (Out put); d). Sistem penerimaan (The receiving system); e). Tujuan pelatihan (The goal of the training)

Dengan demikian, kegiatan pelatihan pada dasarnya dilaksanakan untuk menghasilkan perubahan tingkah laku dari orang-orang yang mengikuti pelatihan. Perubahan tingkah laku yang dimaksud di sini adalah dapat berupa bertambahnya pengetahuan, keahlian, keterampilan, dan perubahan sikap dan perilaku. Oleh karena itu sasaran pelatihan dapat dikategorikan ke dalam beberapa tipe tingkah laku yang diinginkan (Jeffey Mello (1999)), antara lain: a). Kategori Kognitif (Pengetahuan), meliputi proses intelektual seperti mengingat, memahami, dan menganalisis. Sasaran pelatihan pada kategori ini adalah untuk membuat orang mempunyai pengetahuan dan keterampilan berfikir. b). Kategori Skill (Keahlian), meliputi trampil, cepat dalam menyelesaikan pekerjaan. Sasaran dalam katagori ini agar karyawan trampil dalam mengerjakan 
pekerjaan. c). Kategori Psikomotorik (Keterampilan), meliputi pengontrolan otot-otot sehingga orang dapat melakukan gerakan-gerakan yang tepat. Sasarannya adalah agar orang tersebut memiliki keterampilan fisik tertentu. d). Kategori Afektif (Sikap), meliputi perasaan, nilai, dan sikap. Sasaran pelatihan dalam kategori ini adalah untuk membuat orang mempunyai sikap tertentu.

\section{Lingkungan Kerja}

Faktor ini terdiri dari dua kategori, yaitu lingkungan sosial pekerjaan (lingkungan kerja terdekat dan tindakan organisasi sebagai keseluruhan) serta kondisi fisik pekerjaan (Stoner dan Freeman, 2002). Dari beberapa penelitian ditemukan bahwa kelompok rekan sekerja dalam lingkungan kerja mempunyai pengaruh yang besar terhadap Etos Kerja dan Disiplin Kerja karyawan (Stoner dan Freeman 2002). Setiap karyawan tentunya menginginkan agar dirinya dapat diterima masuk sebagai anggota dalam kelompok rekan sekerja, tempat dimana mereka bekerja. Pimpinan juga dapat mempengaruhi karyawan melalui gaya memimpin, kebijaksanaan personalia, suri tauladan, instruksi, pemberian sanksi maupun pemberian pujian atau penghargaan dan lain sebagainya. Semua organisasi di pengaruhi oleh sistem politis dalam lingkungannya. Organisasi harus mematuhi undangundang lokal, negara, dan internasional, maupun regulasi sekiranya mereka ingin tetap bertahan hidup. Kalangan manajer perlu menyadari betul bahwa pada akhirnya setiap aspek kiprah bisnis mereka akan dipengaruhi oleh pertimbangan hukum. Desain pekerjaan juga dipengaruhi oleh peraturan pemerintah. Manajemen mungkin ingin merancang sebuah pekerjaan dengan cara yang dapat meningkatkan kinerja karyawannya, tetapi dalam melakukan hal itu akan mempertimbangkan undang-undang perburuhan atau standar lingkungan maupun keselamatan kerja.

Ekspektasi Sosial kemampu terimaan sebuah desain pekerjaan sebagian diakibatkan oleh ekspektasi sosial. Kultur, etika kerja, dan agama semuanya membantu terbentuknya ekspektasi sosial. Contohnya adalah mengalirnya tenaga kerja kasar dari desa ke kota besar. Mereka pada umumnya bersedia menerima pekerjaan dengan upah rendah yang bersifat rutin, sulit secara fisik, dan menuntut hari kerja yang panjang dan melelahkan. Pekerja-pekerja ini biasanya bersedia menerima pekerjaan kasar karena mereka telah meninggalkan desa mereka di mana pekerjaan sulit didapat. Kendatipun demikian, dewasa ini para karyawan terutama yang ada di kota-kota besar telah mengenyam pendidikan yang lebih tinggi dan mengharapkan kualitas kehidupan kerja yang lebih baik dari pekerjaan mereka. Kegagalan memenuhi ekspektasi itu dapat menyulut motivasi kerja yang rendah, ketidakpuasan, kinerja yang buruk, dan ketidakhadiran dan putaran karyawan yang tinggi.

Kultur organisasi juga mempunyai pengaruh terhadap peningkatan dan penurunan produktivitas kerja, karena kultur organisasi yang sesuai dengan kepribadian akan meningkatkan motivasi dan produktivitas kerja.

\section{Faktor Lingkungan Sosial Pekerjaan}

Lingkungan Sosial pekerjaan dapat dilihat dari lingkungan kerja terdekat yang meliputi tindakan dan sikap rekan maupun pimpinan serta "iklim" yang mereka ciptakan. Kebanyakan orang menginginkan persahabatan dari rekan sekerja yang sesuai dengan nilai dan norma rekan kerjanya. Pimpinan suatu perusahaan sangat mempengaruhi motivasi dan prestasi kerja karyawan dengan suri tauladan dan instruksi, melalui imbalan dan sanksi yang berkisar dari pujian dan promosi sampai dengan kritik, penurunan pangkat dan pemecatan. 
Kultur organisasi, norma, nilai dan keyakinan bersama anggotanya dapat menurunkan atau meningkatkan prestasi kerja individu. Karyawan menganggap kepribadian tidak cocok dengan kultur oganisasi tidak akan sama besar motivasinya. Di samping itu jenis kultur tertentu mungkin lebih berhasil memotivasi karyawan dari pada kultur lainnya.

\section{Faktor Lingkungan Fisik Pekerjaan}

Setiap kantor mempunyai persyaratan lingkungan fisik yang harus pula diperhatikan dan diatur sebaik-baiknya oleh setiap manajer perkantoran yang modern. Yang dimaksud dengan kondisi fisik pekerjaan pada penelitian ini adalah: a). Suhu dan kelembaban udara; Mengenai faktor udara ini, yang penting sekali ialah suhu udara dan banyaknya uap air pada udara tersebut. Tubuh manusia secara terus-menerus mengeluarkan panas agar dapat hidup terus. Suhu manusia yang normal itu $37^{\circ}$ celcius, namun bila seseorang itu bekerja pada suhu tersebut akan tidak efektif. Temperatur yang layak harus dipertahankan dalam ruang kerja minimum 16 derajat celcius atau sama dengan 61 derajat Fehrenheit. Di dalam ruang kerja harus terdapat pertukaran udara yang cukup sehingga dapat menyebabkan kesegaran fisik karyawan. Sebaliknya, pertukaran udara yang kurang akan menimbulkan rasa pengap dan mudah menimbulkan kelelahan. Untuk itu dapat diusahakan dengan kipas angin, AC dan sebagainya. Menggunakan AC pada tempat-tempat yang udaranya pengap menimbulkan kesejukan sehingga dapat mengurangi kelelahan. b). Penerangan / cahaya; Cahaya penerangan yang cukup dan memancar dengan tepat akan menambah efisiensi kerja para karyawan, karena mereka dapat bekerja dengan lebih cepat, lebih sedikit membuat kesalahan dan matanya tidak lekas menjadi lelah. Banyak ketidak beresan pekerjaan disebabkan oleh penerangan yang buruk, misalnya ruangan terlalu gelap atau karyawan-karyawan harus bekerja dibawah penerangan yang menyilaukan. Pengaturan penerangan merupakan hal yang esensial agar orang dapat melaksanakan pekerjaannya. Selain daya penerangan maka akibat silau penerangan perlu diperhatikan, bila tidak akan mengganggu pemandangan atas obyek. Jadi letak lampu/penerangan harus sedemikian rupa hendaknya diperhatikan; makin luas ruangan, intensitas penerangan makin diperlukan dan penyebarannya merata. Jenis peneranganpun perlu dipertimbangkan, yakni alamiah, lampu biasa, neon atau kombinasinya, masing-masing dengan kebaikan dan keburukannya. c). Kebisingan; Kebisingan merupakan gangguan sehingga dengan adanya kebisingan ini konsentrasi dalam bekerja akan terganggu. Selain intensitas dan suara yang tinggi dan tak tentu datangnya akan mengganggu karyawan dalam melaksanakan pekerjaan. Sistem akustik akan dapat mengatur getaran-getaran suara yang membisingkan telinga pekerja, sehingga dapat dengan tenang, terkonsentrasi dalam menjalankan pekerjaannya. Biasanya diusahakan untuk mengisolasi sumber suara dan apabila ini tidak berhasil, maka ruangan diberi alat-alat peredam suara atau ruangan diberi lubang-lubang untuk mengeluarkan suara. Dengan pengaturan suara maka jelas pekerja tidak akan terganggu oleh suara gaduh sehingga dia mempunyai perhatian penuh pada tugasnya, waktu penyelesaian pekerjaan lebih cepat dan kualitas pekerjaan dapat diandalkan. d). Warna dinding dan lantai; Warna merupakan faktor yang penting untuk memperbesar efisiensi kerja para karyawan. Khususnya warna akan mempengaruhi keadaan jiwa mereka. Dengan memakai warna yang tepat pada dinding ruangan dan alat-alat lainnya, kegembiraan dan ketenangan bekerja para karyawan akan terpelihara. Selain itu warna yang tepat juga akan mencegah kesilauan yang mungkin timbul karena cahaya yang berlebihan. Warna putih dinding ruangan adalah netral. Warna biru, hijau dan merah muda dapat menenangkan syaraf. Warna merah, kuning dan orange dapat memacu syaraf yang dapat mengendorkan 
kegiatan. Dengan demikian bila orang ingin karyawannya bekerja dengan giat maka dinding dapat dicat dengan warna yang dapat memacu prestasi kerja para karyawan. Hendaknya diperhatikan waktu istirahat, apabila hal ini tidak diperhatikan, maka orang akan cepat lelah, sehingga dapat mengakibatkan menurunnya produktivitas kerja. e). Kesehatan dan keamanan kerja; Apabila tempat kerja tidak sehat, maka karyawan dan perusahan akan rugi karena harus menanggung beban kecelakaan, tidak masuk kerja dan kematian. Oleh karena itu, karyawan perlu perlindungan di tempat kerjanya, baik dari keadaan yang tidak aman dalam bekerja atau karena terkena penyakit sebab tempat kerja tidak bersih. Adapun caranya ialah memberikan informasi untuk selalu berhati-hati, membersihkan ruangan kerja. Akhirnya mengenai pengaturan kebersihan tempat dan keamanan tergantung pada masing-masing tempat kerja. f). Keselamatan kerja; Disebutkan bahwa tempat kerja yang bersih, suara gaduh yang dapat dikendalikan, warnanya menenangkan dan udara yang bersih serta nyaman akan menghasilkan peningkatan produktivitas kerja. Selain itu orang akan terhindar dari kelesuan kerja dan sekaligus mencegah terjadinya kecelakaan selama bekerja. Walaupun disatu pihak orang tetap berusaha mencegah terjadinya kecelakan dengan berbagi alat, namun pencegahan dini dapat dilakukan dengan menjaga kondisi fisik karyawan. Oleh karena itu karyawan harus didorong dan dimungkinkan untuk mempertahankan kondisi badaniyahnya dengan anjuran mengkonsumsi makanan bergizi. Selain itu diatur juga tentang motivasi bekerja yang lain yaitu kondisi sosial dan kebutuhan individu baik fisiologi dan sosial, disamping disiapkan juga kemampuan mereka terutama dalam hal ketrampilan dan pengetahuan. Diharapkan dengan diperhatikannya hal-hal tersebut diatas maka keselamatan karyawan dilindungi, yang pada gilirannya akan meningkatkan produktivitas kerja karyawan itu sendiri. Yang dimaksud dengan pengaturan lingkungan kerja adalah pengaturan penerangan tempat kerja, pengontrolan terhadap suara gaduh, pengontrolan terhadap udara, pengaturan kebersihan tempat kerja dan pengaturan tentang keamanan kerja serta keselamatan kerja.

Lingkungan kerja ini dikenal juga sebagai lingkungan fisiologi dan mempengaruhi kerja produktivitasnya, disamping pengaruh dari faktor ukuran jasmaniah, faktor neurologik serta faktor otot.

Kinerja pada dasarnya adalah apa yang dilakukan atau tidak dilakukan karyawan. Kinerja karyawan adalah yang mempengaruhi sebanyak mereka memberi kontribusi kepada organisasi, yang antara lain termasuk: 1). Kuantitas output; 2). Kualitas output; 3). Jangka waktu output; 4). Kehadiran di tempat kerja; 5). Sikap kooperatif (Robert L Mathis \& John H Jeckson, 2002).

Bekerja merupakan kegiatan manusia untuk merubah keadaan tertentu dari alam lingkup yang ditunjukan untuk memenuhi kebutuhan hidup, mempertahankan dan memelihara hidupnya. Dalam proses bekerja itulah, maka seseorang dapat dilihat bagaimana kinerjanya.

Banyak batasan yang diberikan para ahli mengenai istilah kinerja walaupun mempunyai visi yang agak berbeda namun secara prinsip setuju bahwa kinerja mengarah pada suatu upaya penerapan prestasi kerja yang lebih baik. Kinerja pada dasarnya adalah apa yang dilakukan atau tidak dilakukan karyawan. Kinerja karyawan adalah yang mempengaruhi seberapa banyak mereka memberi kontribusi kepada organisasi, antara lain ; kuantitas output, kualitas output, jangka waktu output, kehadiran ditempat kerja, sikap kooperatif. (Robert L. Mathis \& John H. Jeckson, 2002).

Menurut Payaman J. Simanjuntak (2005), kinerja adalah tingkat pencapaian hasil atas pelaksaan tugas tertentu. Kinerja perusahaan adalah tingkat pencapaian hasil dalam 
rangka mewujudkan tujuan perusahaan. Lebih lanjut Payaman J. Simanjuntak, menyatakan bahwa konsep kinerja sama halnya dengan konsep produktivitas, konsep produktivitas nilai hasil yang dicapai dibandingkan dengan masukan yang digunakan. Sementara dalam konsep kinerja, hasil yang dicapai dibandingkan terhadap sasaran atau rencana yang telah ditetapkan lebih dahulu. Konsep produktivitas harus memperhitungkan nilai masukan, sementara konsep kinerja lebih menekankan kesesuaian pen capaian hasil dengan rencana.

Keberhasilan suatu organisasi adalah ditentukan oleh seberapa baik para karyawan dapat mengelola kinerja, yang merupakan tanggung jawab yang utama untuk memperoleh hasil akhir (kinerja), dengan menggunakan semua sumber daya yang dimiliki atau diakses.

Oleh karena itu kinerja pada hakekatnya berarti suatu hasil akhir atau titik akhir orang, sumber daya, dan lingkungan tertentu yang dikumpulkan bersama-sama dengan maksud untuk menghasilkan hal-hal tertentu dapat berupa produk atau jasa. Jadi dapat disimpulkan bahwa tingkat kinerja tertinggi diperoleh apabila karyawan dapat melaksanakan pekerjaannya pada tingkat yang diinginkan dengan sedikit atau bahkan tanpa adanya pengawasan.

Kinerja disebut juga kinerja enerjik kerja atau performance. Kinerja adalah fungsi dari hasil atau apa yang dicapai oleh seorang karyawan dan kompetensi yang dapat menjelaskan bagaimana karyawan dapat mencapai hasil tersebut. Dijelaskan lebih lanjut mengenai manajemen kinerja yang merupakan suatu proses komunikasi yang menciptakan pemahaman bersama antara atasan-bawahan mengenai apa yang harus dicapai atau hasil akhir dan bagaimana mencapainya atau kompetisi sehingga akan meningkatkan kemungkinan tercapainya sasaran yang ditetapkan.

Kinerja adalah suatu hal yang dicapai oleh para pekerja dalam pekerjaannya menurut kriteria tertentu yang berlaku untuk suatu pekerjaan tertentu dan evaluasi oleh orang-orang tertentu. Kinerja suatu organisasi itu dicapai menurut kriteria tertentu oleh orang tertentu dan nilai oleh orang tertentu. Kenyataan di lapangan bahwa kinerja seorang karyawan dinilai berhasil atau tidak oleh golongan atau kelompok tertentu tetapi dinilai oleh masyarakat luas jadi kinerja karyawan dilingkungan Pemerintah Daerah tidak bisa dinilai oleh golongan tertentu saja.

Pada umumnya orang-orang yang berkesinambungan dalam manajemen sumber daya manusia sependapat bahwa penilaian prestasi kerja para karyawan merupakan bagian terpenting dari seluruh proses kekaryaan karyawan yang bersangkutan. Pentingnya penilaian prestasi kerja yang rasional dan diterapkan secara objektif terlihat pada paling sedikit dua kepentingan yaitu kepentingan karyawan yang bersangkutan sendiri dan kepentingan organisasi.

Bagi para karyawan penilaian tersebut sebagai umpan balik tentang hal kemampuan, keletihan, kekurangan dan potensinya yang pada gilirannya bermanfaat untuk menentukan tujuan, rencana dan pengembangan kariernya. Bagi organisasi, hasil penelitian prestasi kerja para karyawan sangat penting arti dan peranannya dalam pengambilan keputusan tentang berbagai hal, seperti identifikasi kebutuhan program pendidikan dan pelatihan, recruitment, seleksi, program pengenalan, penempatan, promosi, system imbalan dan berbagai aspek lain dari keseluruhan proses manajemen sumber daya manusia secara efektif.

Tingkat pencapaian pelaksanaan tugas seseorang atau evaluasi kinerja kelompok membutuhkan adanya tolok ukur sebagai alat pembanding atau alat ulur. Menurut Payaman J. Simanjuntak (2005), menyatakan bahwa tolok ukur dapat berbeda-beda sesuai dengan sifat pekerjaan atau jabatan masing-masing. Beberapa jenis tolok ukur tersebut antara lain : 1). Sasaran atau target sebagaiman yang telah dirumuskan atau dinyatakan 
dalam rencana kerja; 2). Standar umum, baik yang ditetapkan sebagai ketentuan atau pedoman oleh instansi resmi, maupun yang diterima secara consessus ditingkat nasional atau internasional; 3). Standar yang telah ditetapkan secara khusus, misalnya dalam menerima kerja kontrak; 4). Uraian tugas atau uraian jabatan menggambarkan pekerjaan, atau tugas yang harus dilaksanakan oleh pejabat yang bersangkutan; 5). Misi dan atau tugas pokok organisasi menggambarkan apa yang harus dicapai oleh organisasi tersebut kurun waktu tertentu.

Masing-masing tolok ukur tersebut pada dasarnya mempunyai dimensi tolok ukur : 1). Kuantitas, yaitu bahwa pencapaian sasaran atau target dalam kuantitas dapat diukur secara absolute, dalam persentase atau indek; 2). Kualitas, yaitu bahwa kualitas bersifat relative, sehingga tidak mudah diukur, dan sangat tergantung pada selera komsumen. Kualitas dapat mencakup daya tahan atau usia penggunaan, desain, dan kenyamanan menggunakannya. Kualitas dapat dirasakan, dilihat atau diraba. Produk-produk berkualitas tinggi dapat dijual dengan harga yang lebih tinggi; 3). Waktu dan kecepatan, yaitu setiap pelaksanaan tugas selalu membutuhkan waktu sebagai masukan. Waktu merupakan sumber daya yang mahal, karena terbatas dan tidak dapat disimpan atau ditunda. Oleh karena itu setiap waktu harus dapat dipergunakan secepat mungkin dan optimal; 4). Nilai dan biaya, yaitu bahwa nilai barang atau jasa yang dihasilkan dapat dinilai dalam harga atau rupiah, dan nilai tersebut perlu dibandingkan terhadap biaya yang dikeluarkan untuk menghasilkan barang. Bila nilai hasil tidak berbeda dengan signifikan atau bahkan hanya sama atau justru lebih kecil dari biaya yang dikeluarkan, hasil kinerja juga menjadi kurang bermakna; 5). Persentase dan indeks, yang menggunakan sistem pembobotan.

Untuk mengukur capaian kinerja instansi pemerintah adalah dengan analisis terhadap capaian kinerja, dilakukan untuk mengetahui lebih jauh sebab-sebab tercapai maupun tidaknya target yang telah ditetapkan. Ukuran tercapai tidaknya sasaran adalah memperhatikan tingkat output atau outcome yang dicapai, jika realisasi yang dicapai sesuai atau melebihi target yang ditetapkan, maka sasaran tersebut dikatakan tercapai, sebaliknya jika realisasi yang dicapai dibawah ini atau kurang dari target yang ditetapkan, maka sasaran tersebut dikatakan tidak tercapai.

\section{METODE}

Penelitian ini menggunakan metode penelitian survei dengan pendekatan explanatory analisis dan prediktif. Fenomena yang terjadi dapat didesain melalui fungsi matematis berikut : $\hat{\mathrm{Y}}=\mathrm{F}\left(\mathrm{X}_{1}, \mathrm{X}_{2} \ldots \ldots . .+\mathrm{X}_{\mathrm{n}}\right)$ model persamaan multivariat, dengan $\hat{\mathrm{Y}}=\mathrm{F}(\mathrm{X})$, model persamaan bivariat.

Populasi dan Sampel penelitian adalah karyawan PT. Coca-Cola Bottling Indonesia yang berjumlah sebanyak 1400 karyawan (data perusahaan, 2010), yang terdistribusi pada posisi staf dan operasional.

Selanjutnya, dalam menetapkan jumlah sampel penelitian didasarkan pada Teori Slovin (2001) dengan asumsi bahwa populasi berdistribusi normal menggunakan rumus :

$$
n=\frac{N}{1+N e^{2}}
$$


Dimana :

$\mathrm{n}=$ Ukuran sampel

$\mathrm{N}=$ Ukuran populasi

$\mathrm{e}=$ Persen kelonggaran ketidaktelitian karena kesalahan pengambilan sampel yang masih dapat ditolerir/diinginkan yaitu sebesar 0,1(10\%)

Dengan rumus Slovin tersebut maka didapat angka $\mathrm{n}$ adalah :

$$
\begin{aligned}
n & =\frac{1400}{1+(1400 \times 0,01)} \\
& =93.33(\text { dibulatkan menjadi } 93 \text { orang })
\end{aligned}
$$

\section{HASIL DAN PEMBAHASAN}

Tabel - 1: Pengaruh Simultan Pelatihan dan Lingkungan Kerja Terhadap Kinerja

\begin{tabular}{|c|c|c|c|c|c|c|c|c|}
\hline \multirow[b]{2}{*}{$\begin{array}{c}\text { Hubungan } \\
\text { Variabel }\end{array}$} & \multicolumn{8}{|c|}{ Paramter } \\
\hline & $\begin{array}{c}\text { Mult. } \\
\text { R }\end{array}$ & $\begin{array}{c}\mathbf{R} \\
\text { Square }\end{array}$ & $\begin{array}{c}\mathrm{t} \\
\text { hitung }\end{array}$ & $\begin{array}{c}\mathrm{t} \\
\text { tabel }\end{array}$ & Konstanta & $\begin{array}{c}\text { Coef. } \\
\text { B }\end{array}$ & Sig & $\boldsymbol{\alpha}$ \\
\hline Pelatihan & \multirow{2}{*}{0.884} & \multirow{2}{*}{0.781} & 4,823 & \multirow{2}{*}{2,631} & \multirow{2}{*}{25,547} & 0,634 & \multirow{2}{*}{0,000} & \multirow{2}{*}{$1 \%$} \\
\hline Ling. Kerja & & & 2,028 & & & 0,362 & & \\
\hline Pengujian S & ifikan & & & & & & & \\
\hline
\end{tabular}
Karyawan PT. Coca-Cola Bottling Indonesia

Keterangan: Variabel Kinerja Karyawan

Sumber: data diolah tahun 2013

Berdasarkan nilai koefisien korelasi pada tabel di atas, hubungan yang terbentuk sangat kuat dan berprediksi positif. Dengan memperhatikan model simultan maka persamaan yang dapat dijelaskan adalah sebagai berikut:

$$
\hat{\mathrm{Y}}=25.547+0.634\left(\mathrm{X}_{1}\right)+0.362\left(\mathrm{X}_{2}\right)+\mathrm{e} .
$$

Didasarkan pada persamaan di atas, faktor pelatihan berprediksi positif $(+)$ dengan koefisien pelatihan $0,634 \mathrm{X}_{1}$ dan faktor lingkungan kerja berprediksi positif $(+)$ dengan koefisien lingkungan kerja $0,362 \mathrm{X}_{2}$. Memperhatikan tampilan tabel diatas menunjukkan bahwa pelatihan dan lingkungan kerja mempunyai pengaruh yang positif terhadap kinerja karyawan, dan pelatihan mempunyai pengaruh yang paling dominan dari pada variabel lain yaitu lingkungan kerja dalam mempengaruhi kinerja karyawan. Hal ini menunjukkan bahwa pelatihan merupakan faktor yang paling menentukan peningkatan kinerja karyawan PT. Coca-Cola Bottling Indonesia di banding dengan lingkungan kerja.

Lebih lanjut dapat dijelaskan, bahwa secara simultan kedua variabel tersebut mampu memprediksikan pengaruh yang positif dan signifikan untuk $\quad \alpha 0.01$ (Perhatikan Prob Sig, 0.000), dan mampu pula memberikan kontribusi yang kuat terhadap perubahan yang linier terhadap kinerja karyawan, perhatikan $R$-Square $=0.781$. Kondisi ini juga 
mampu menjelaskan, bahwa pelatihan dan lingkungan kerja secara simultan memberikan pengaruh terhadap kinerja karyawan dengan pengaruh sebesar $78 \%$, dan sisanya atau sebesar $22 \%$ adalah sebagai Un explaned Residual yaitu pengaruh variabel lain di luar model.

\section{Tabel - 2: Pengaruh Parsial Pelatihan Terhadap Kinerja Karyawan PT. Coca-Cola Bottling Indonesia}

\begin{tabular}{|l|c|c|c|c|c|c|c|c|}
\hline \multirow{2}{*}{$\begin{array}{c}\text { Hubungan } \\
\text { Variabel }\end{array}$} & \multicolumn{9}{|c|}{ Paramter } \\
\cline { 2 - 9 } & $\begin{array}{c}\text { Mult. } \\
\text { R }\end{array}$ & $\begin{array}{c}\mathbf{R} \\
\text { Square }\end{array}$ & $\begin{array}{c}\mathbf{t} \\
\text { hitung }\end{array}$ & $\begin{array}{c}\mathbf{t} \\
\text { tabel }\end{array}$ & Konstanta & $\begin{array}{c}\text { Coef. } \\
\mathbf{B}\end{array}$ & Sig & $\boldsymbol{\alpha}$ \\
\hline Pelatihan & $\mathbf{0 . 8 1 2}$ & $\mathbf{0 . 6 5 9}$ & $\mathbf{4 , 0 8 7}$ & $\mathbf{2 , 6 3 1}$ & $\mathbf{1 5 , 3 5 5}$ & $\mathbf{0 , 6 1 8}$ & $\mathbf{0 , 0 0 0}$ & $\mathbf{1 \%}$ \\
\hline
\end{tabular}

Keterangan: Variabel Kinerja Karyawan

Sumber: data diolah tahun 2013

Memperhatikan tampilan tabel diatas menunjukkan bahwa pelatihan mempunyai pengaruh yang positif terhadap kinerja karyawan. Lebih lanjut dapat dijelaskan, bahwa secara parsial variabel pelatihan mampu memprediksikan pengaruh yang positif dan signifikan untuk $\alpha 0.01$ (Perhatikan Prob Sig, 0.000), dan mampu pula memberikan kontribusi yang kuat terhadap kinerja karyawan, perhatikan $R$-Square $=0.659$. Kondisi ini juga mampu menjelaskan, bahwa pelatihan secara parsial memberikan pengaruh sebesar $66 \%$ terhadap kinerja karyawan.

Dari persamaan regresi parsial diatas dapat dilihat arah hubungan yang dihasilkan dari variabel bebas terhadap variabel terikatnya, dengan asumsi variabel lain konstan yaitu $: \hat{y}=15.355+0.618\left(X_{1}\right)+e$

Koefisien regresi variabel $\mathrm{X}_{1}$ bertanda positif menunjukkan adanya hubungan yang positif dari variabel pelatihan yang menyebabkan kenaikan sebesar 0.618 dan signifikan untuk prob sig 0.000 (Signifikan untuk $\alpha$ 0.01) terhadap kinerja karyawan. Melalui penduga ini dapat digambarkan, bahwa pelatihan memberikan indikasi pengaruh yang positif. Pengaruh parsial tersebut, diprediksikan untuk penduga Constanta adalah positif sebesar 15.355. Artinya secara parsial variabel prediktor tersebut memberikan dampak fluktuatif yang linier terhadap kinerja karyawan dengan tingkat signifikansi yang sangat baik

Tabel - 3: Pengaruh Parsial Lingkungan Kerja Terhadap Kinerja Karyawan PT. Coca-Cola Bottling Indonesia

\begin{tabular}{|l|c|c|c|c|c|c|c|c|}
\hline \multirow{2}{*}{$\begin{array}{c}\text { Hubungan } \\
\text { Variabel }\end{array}$} & \multicolumn{9}{|c|}{ Paramter } \\
\cline { 2 - 9 } & $\begin{array}{c}\text { Mult. } \\
\mathbf{R}\end{array}$ & $\begin{array}{c}\mathbf{R} \\
\text { Square }\end{array}$ & $\begin{array}{c}\mathbf{t} \\
\text { hitung }\end{array}$ & $\begin{array}{c}\mathbf{t} \\
\text { tabel }\end{array}$ & Konstanta & $\begin{array}{c}\text { Coef. } \\
\mathbf{B}\end{array}$ & Sig & $\boldsymbol{\alpha}$ \\
\hline Ling. Kerja & $\mathbf{0 , 6 8 6}$ & $\mathbf{0 , 4 7 1}$ & $\mathbf{2 , 0 0 5}$ & $\mathbf{2 , 6 3 1}$ & $\mathbf{9 , 3 5 0}$ & $\mathbf{0 , 4 2 2}$ & $\mathbf{0 , 0 0 0}$ & $\mathbf{1 \%}$ \\
\hline
\end{tabular}

Keterangan: Variabel Kinerja Karyawan

Sumber: data diolah tahun 2013

Memperhatikan tampilan tabel diatas menunjukkan bahwa lingkungan kerja mempunyai pengaruh yang positif terhadap kinerja karyawan. Lebih lanjut dapat dijelaskan, bahwa secara parsial variabel lingkungan kerja mampu memprediksikan pengaruh yang positif dan signifikan untuk $\alpha 0.01$ (Perhatikan Prob Sig, 0.000), dan 
mampu pula memberikan kontribusi yang cukup kuat terhadap kinerja karyawan, perhatikan $R$-Square $=0.471$. Kondisi ini juga mampu menjelaskan, bahwa lingkungan kerja secara parsial memberikan pengaruh sebesar $47 \%$ terhadap kinerja karyawan.

Dari persamaan regresi parsial diatas dapat dilihat arah hubungan yang dihasilkan dari variabel bebas terhadap variabel terikatnya, dengan asumsi variabel lain konstan yaitu $: \hat{y}=9.350+0.422\left(\mathrm{X}_{2}\right)+\mathrm{e}$

Koefisien regresi variabel $\mathrm{X}_{2}$ bertanda positif menunjukkan adanya hubungan yang positif dari variabel lingkungan kerja yang menyebabkan kenaikan sebesar 0.422 dan signifikan untuk prob sig 0.000 (Signifikan untuk $\alpha$ 0.01) terhadap kinerja karyawan. Melalui penduga ini dapat digambarkan, bahwa lingkungan kerja memberikan indikasi pengaruh yang positif. Pengaruh parsial tersebut, diprediksikan untuk penduga Constanta adalah positif sebesar 9.350. Artinya secara parsial variabel prediktor tersebut memberikan dampak fluktuatif yang linier terhadap kinerja karyawan dengan tingkat signifikansi yang sangat baik.

\section{KESIMPULAN DAN SARAN}

\section{Kesimpulan}

Dari hasil analisis dan pembahasan yang tertuang, menunjukkan bahwa pelatihan dan lingkungan kerja dapat meningkatkan kinerja karyawan namun secara spesifik hasil penelitian ini adalah: 1). Secara simultan pelatihan dan lingkungan kerja dapat berpengaruh secara positif, relatif kuat dan signifikan terhadap kinerja karyawan PT. Coca-Cola Bottling Indonesia. Hal ini ditunjukkan dengan perolehan korelasi yang dihasilkan relatif sangat erat dengan perolehan Rho (R) $88 \%$ dan kontribusi/determinasi yang relatif kuat terhadap kinerja karyawan, hal ini dapat dibuktikan melalui hasil perolehan $\mathrm{R}^{2}$ sebesar $78 \%$ dan sisanya atau sebesar $22 \%$ adalah sebagai Estimasi residual yang Un explaned Residual yang dipengaruhi oleh variabel lain di luar model, 2). Secara parsial pelatihan dapat berpengaruh positif, relatif kuat dan signifikan terhadap kinerja karyawan. Hal ini dibuktikan dengan perolehan kontribusi/determinasi yang kuat dengan R-Square $=66 \%$. 3). Secara parsial lingkungan kerja dapat berpengaruh positif, relatif cukup kuat dan signifikan terhadap kinerja karyawan. Hal ini dibuktikan dengan perolehan kontribusi/determinasi yang relatif cukup kuat atau R-Square $=47 \%$.

\section{Saran - Saran}

Setelah menarik kesimpulan, maka peneliti mencoba untuk memberikan saran, yang sekiranya dapat dijadikan rekomendasi khususnya bagi PT. Coca-Cola Bottling Indonesia yang dijadikan obyek penelitian maupun perusahaan sejenis: a). Memperhatikan pelatihan di PT. Coca-Cola Bottling Indonesia sudah cukup berhasil dalam melaksanakan pelatihan, tapi agar lebih optimal maka perusahaan harus lebih memperhatikan tentang waktu pelatihan dan pemberian materi yang tepat dan disesuikan dengan kebutuhan dimasa mendatang, agar pelaksanaan pelatihan tepat sasaran dan tidak mengganggu pekerjaan peserta pelatihan. b). Disarankan kepada manajemen untuk memperhatikan lingkungan kerja disekitar para karyawan dengan membangun infrastruktur untuk lingkungan fisik, perusahaan juga memperhatikan lingkungan sosial misalnya dengan membangun kerjasama dan komunikasi yang baik antara atasan dan bawahan. c). Diharapkan penelitian 
ini dapat dijadikan bahan pertimbangan khususnya bagi manajemen PT. Coca-Cola Bottling Indonesia untuk meningkatkan lagi pelatihan dan lingkungan kerja dengan demikian kinerja karyawan akan meningkat dan diharapkan penelitian ini dapat dijadikan masukan bagi penelitian selanjutnya.

\section{DAFTAR PUSTAKA}

Ahmad Aldel Halim, 1999, Management. Fouth Edition. Edisi Bahasa Indonesia oleh Susilo Martoyo, Enggelwood Cliffs. New Jersey

Algivari. 1997, Pengantar Metode Statistik II, Jakarta: PT. Pustaka LP3ES.

Al Rasyid, Harun, 1998, (Penyunting : Teguh Kismantoroadji, dkk), Dasar-Dasar Statistika Terapan, Program Pascasarjana, Unpad : Bandung.

As'ad, Moh. 2002, Psikologi Industri, Yogyakarta : Liberty.

Astrid. 1997, Guide for Supervisor, Alih Bahasa, Jakarta: Elex Media Komputindo.

Blum \& Taylor. 1996, Human Resource Strategy, McGraw-Hill (Wal). Singapure.

Buhler. 1994, Conducting Educational Research, San Diego: Harcout Brace Jovanovich. Publisher.

Cascio 2001, Fair Discipline, Washington D.C: Bureau of National Affair, Inc Handoko. 1998, Manajemen Sumber Daya Manusia, Yogyakarta : STIE YKPN. Judith. 1998, Notes on The Concept of Commitment, American Journal of Sociology. Lind. 2002, Korelasi Dan Analisis Regresi Berganda, Nur Cahaya.

Locke. 1997, Organization. Work. and Personal Factors in Employee Turnover and Absenteem, Psychological Bulletin.

Mill Robert (1992), Human Resource Management. A Strategic Approoch forth Worth : The Dryden Press.

Natalie Allen 1995, Organizational Commitment: Evidence of Career Stage Effects?. Journal of Business Research

Purwantini. 2005, Analisis Pengaruh lingkungan kerja dan disiplin kerja terhadap produktivitas kerja pegawai, PT. Bayer Indonesia.

Rd. Ogana Lopiana. 2008. "Analisis faktor lingkungan kerja dan kompensasi terhadap kepuasan kerja pegawai, PT. Efrata Jaya Express (EJE)".

Robbins, S. 1997, Perilaku Organisasi, PT. Prenhallido, Jakarta.

Setiaji. 2004, Panduan Riset dengan Pendekatan Kuantitatif, Program Pasca Sarjana UMS. Surakarta.

Slovin. 2001, Sampling: A Quick Reliable Guide to Practical Statistics, New Yoek: Simon and Schuster.

Sondang P. Siagian, 1996, Manajemen Dan Evaluasi Kinerja, Jakarta : PT. Payaman Pustaka Binaman Pressindo.

Stoner dan Freeman, 2002, Behavior In Organization: Understanding and Managing the Human Side of Work (Englewood Cliff: Prentice-Hall).

Stoner, James AF, 1994, Manajemen, Alih bahasa Susilo Martoyo (Jakarta: Intermedia).

Stephen P. Robbins. 1996, Employee- Organization Linkages: The Psychology of Commitment. Absenteeism. and Turnover, New York: Academic Press.

1998, Perilaku Organisas,. Alih Bahasa Hadyanan Pujaatmika. Jakarta: PT. Prenhallindo.

Suryo Admojo, 2001, Tata Cara Managemen, Surakarta: Cendrawasih 
Thomas J. Burns, 1997, Strategy Implementation: The Role Of Structures And Process, St. Paul : West Publishing.

Umar. Husein, 1998, Riset Sumber Daya Manusia Dalam Organisasi, Cetakan Ketiga. PT. Gramedia Pustaka Utama. Jakarta.

Werther \& Davis, 1996, Developing Organizations: Diagnosys and Action, San Francisco : Mc Graw Hill Book Company. 